\title{
Pathobiology of Cast Nephropathy from Human Bence Jones Proteins
}

Paul W. Sanders and Beverly B. Booker

Nephrology Research and Training Center and Division of Nephrology, Departments of Medicine and Physiology,

University of Alabama at Birmingham and Veterans Administration Medical Center, Birmingham, Alabama 35294

\begin{abstract}
Renal failure is a common accompaniment of multiple myeloma and is usually due to cast nephropathy, or "myeloma kidney." To understand this lesion, four human Bence Jones proteins (BJP) were purified from the urine of volunteers who had either no evidence of renal dysfunction (BJP1) or renal failure from cast nephropathy (BJP2, BJP3, BJP4). When infused directly into the rat nephron in vivo, BJP2, BJP3, and BJP4 produced intraluminal obstruction by precipitating in the distal nephron; protein casts were never identified before the tip of the loop of Henle. Obstruction was related to the concentration of BJP in the perfusate. Addition of furosemide to the perfusate augmented obstruction in a concentration-dependent fashion. Pretreatment of rats with colchicine completely prevented obstruction and cast formation of perfused nephrons; $\beta$-lumicolchicine did not prevent obstruction. Tamm-Horsfall glycoprotein purified from $\beta$-lumicolchicine-treated and untreated rats coaggregated with BJP3 in vitro. Tamm-Horsfall glycoprotein from colchicine-treated rats did not contain sialic acid and did not aggregate with BJP3 in vitro.

Thus, cast-forming human BJP coaggregated with TammHorsfall glycoprotein and obstructed the rat distal nephron. Intranephronal obstruction was aggravated by decreasing extracellular fluid volume or adding furosemide. Finally, by decreasing secretion and altering the carbohydrate moiety of Tamm-Horsfall glycoprotein, colchicine prevented intraluminal cast formation and obstruction of the rat nephron. ( $J$. Clin. Invest. 1992. 89:630-639.) Key words: colchicine • furosemide • microperfusion • myeloma kidney • protein interaction • Tamm-Horsfall glycoprotein
\end{abstract}

\section{Introduction}

Since the original description of urinary Bence Jones proteins (1) and their subsequent characterization as immunoglobulin light chains $(2,3)$, these low molecular weight proteins have been shown to produce renal failure by causing both glomerular and tubular damage (4-8). Tubulotoxic Bence Jones proteins either collect in the endolysosomal system of the proximal tubule epithelium and damage these cells directly, or precipitate in the tubule lumen to form casts (5-15). In humans, intra-

Portions of this work were published in abstract form (1990. Kidney Int. 37:494; 1990. J. Am. Soc. Nephrol. 1:618; 1991. Clin. Res. 39:248A).

Address reprint requests to Dr. Sanders, Division of Nephrology, Department of Medicine, 642 Lyons-Harrison Research, University of Alabama at Birmingham, Birmingham, AL 35294.

Received for publication 6 September 1991.

J. Clin. Invest.

(C) The American Society for Clinical Investigation, Inc.

$0021-9738 / 92 / 02 / 0630 / 10 \quad \$ 2.00$

Volume 89, February 1992, 630-639 luminal precipitation of Bence Jones proteins is characteristic of cast nephropathy, or "myeloma kidney." This classic renal lesion associated with Bence Jones proteinuria can occur acutely and is identified morphologically by the presence of multiple intraluminal proteinaceous casts that contain the immunoglobulin light chain and Tamm-Horsfall glycoprotein (4). Cast nephropathy is reproduced in the rat with intravenous infusion or direct intratubular perfusion of purified human Bence Jones proteins $(5,7,10-12,14,15)$. We have shown (15) that human Bence Jones proteins that precipitate in vivo in the rat coaggregate in vitro with human Tamm-Horsfall glycoprotein, which is secreted into the tubule lumen by cells of the thick ascending limb of the loop of Henle $(16,17)$. Coaggregation of these proteins depends upon the ionic environment in that increasing concentrations of calcium, sodium, and chloride augment this interaction (15). Thus, Tamm-Horsfall glycoprotein and the ionic composition of tubule fluid appear to play pivotal roles in cast formation from these proteins.

We designed the current studies to characterize completely (a) the site and functional significance of intraluminal protein precipitation, and $(b)$ those factors that modulate this phenomenon.

\section{Methods}

Protein preparation and analysis. Four human Bence Jones proteins (BJP) ${ }^{1}$ were used. BJP1 was a $x$ immunoglobulin light chain obtained from a patient who had no clinical evidence of renal dysfunction. BJP2 was a $x$ light chain obtained from a patient who had renal failure and histopathologic changes typical of cast nephropathy from Bence Jones proteinuria. Both of these proteins were generous gifts from Dr. Alan Solomon at the University of Tennessee Medical Center at Knoxville. BJP2 reproduced renal failure and cast formation in a mouse model (7). BJP3 and BJP4 were, respectively, $\lambda$ and $\kappa$ light chains purified from the urine of patients who had multiple myeloma and renal failure by using previously described techniques that included ammonium sulfate precipitation, ion exchange chromatography, and extensive dialysis $(12,14)$. BJP3 has been used extensively in our laboratory and has been shown to be a cast-forming protein in vivo $(14,15)$. BJP4 was donated by a patient who had renal failure and biopsy-proven cast nephropathy. Albumin (ALB) (bovine serum albumin, fraction V, essentially fatty acid-free, Sigma Chemical Co., St. Louis, MO) was also used. Tamm-Horsfall glycoprotein was purified from the urine of rats using the original protocol of Tamm and Horsfall (18). Protein analysis-purity, molecular weights, isotypes, isoelectric points-was performed as described previously using electrophoresis on $12 \%$ polyacrylamide gels containing $0.1 \%$ sodium dodecyl sulfate (SDS-PAGE) under reducing and nonreducing conditions, Western blotting, and isoelectric focusing $(12,14,15)$.

Animal preparation. Description of the anesthesia and surgical preparation of the rats used for in vivo microperfusion has been standardized in our laboratory and reported in detail $(12,14,15)$. Briefly, male

1. Abbreviations used in this paper: ALB, albumin; BBS, boratebuffered saline; BJP, Bence Jones protein; BW, body weight. 
Sprague-Dawley rats (Charles River Breeding Laboratories, Inc., Wilmington, MA, and Harlan Sprague Dawley, Prattville, AL), which weighed between 180 and $289 \mathrm{~g}$ (mean, $228 \pm 3 \mathrm{~g}$ ) and were maintained on standard rat laboratory diet (Prolab 1000, Agway, Syracuse, NY) and tap water ad libitum, were anesthetized with ethyl, 1-methylpropylthiobarbiturate (Inactin, BYK Gulden, Federal Republic of Germany), $75-100 \mathrm{mg} / \mathrm{kg}$ body weight (BW), intraperitoneally. After placement on a servo-controlled heated table, tracheostomy was performed, followed by cannulation of the right external jugular vein for infusion of Ringer-bicarbonate containing $2 \%$ polyfructosan (Inutest, Laevosan-Gesellschaft, Linz, Austria) at rates described below. The right femoral artery was cannulated to sample blood and to monitor arterial pressure using a transducer (model 4-327-I Physiological Pressure Transducer, Telos Medical Corp., Upland, CA) attached to MacLab Data Acquisition System (World Precision Instruments, Inc., New Haven, CT). The bladder was catheterized through a suprapubic route for urine collections. The left kidney was exposed through a subcostal incision and was placed in a Lucite cup. A well was formed on the surface of the kidney with $4 \%$ agar and filled with warmed Ringer-bicarbonate.

Single-nephron perfusion technique. After a 1-h equilibration period, arterial blood was sampled for determination of hematocrit, plasma osmolality, and plasma sodium, potassium, chloride, and protein concentrations, and microperfusion was begun. Initially, proximal tubule pressures were measured at random in four to six nephrons using a servo-nulling micropressure system (model 5A, Instrumentation for Physiology \& Medicine, Inc., San Diego, CA) and were averaged. A pipet filled with Food, Drug and Cosmetic (FD\&C) Green No. 3-tinted (Keystone Aniline and Chemical Co., Chicago, IL) artificial tubular fluid was inserted into a proximal tubule at random and a small bolus injected to identify a nephron that had multiple surface proximal convolutions. The artificial tubular fluid was similar in composition to that of fluid in the early proximal tubule and contained (in $\mathrm{mM}$ ): 95 $\mathrm{NaCl}, 25 \mathrm{NaHCO}_{3}, 5 \mathrm{KCl}, 0.6 \mathrm{CaCl}_{2}, 3.1 \mathrm{NaH}_{2} \mathrm{PO}_{4}, 6 \mathrm{Na}_{2} \mathrm{HPO}_{4}, 7.5$ D-glucose, and 4.5 urea. A pipette attached to the micropressure monitoring system was then inserted into a late surface proximal convolution to monitor continuously proximal tubule pressure. A bone wax cast was inserted into an early proximal segment to obstruct completely flow through the nephron. Just distal to this block, a pipet was inserted into a proximal convolution to perfuse the remainder of the nephron. The perfusion pipet was filled with FD\&C Green-tinted artificial tubular fluid containing one of the test proteins. The perfusion pipet was connected to a pressure-driven perfusion apparatus which consisted of an airtight Erlenmeyer flask attached to a syringe and a pressure gauge. Perfusion pressure was adjusted in the initial few seconds of the experiment until the previously determined average proximal tubule pressure was attained. Perfusion pressure was then kept constant. In all experiments, perfusion was stopped arbitrarily if proximal tubule pressure rose to $20 \mathrm{~mm} \mathrm{Hg}$ or if proximal tubule pressure did not increase after $60 \mathrm{~min}$ of perfusion. Subsequently, the perfused nephrons were dissected and examined with a dissecting microscope (model M3Z, Wild, Heerbrugg, Switzerland).

The ability of this pressure-sensitive perfusion system with continuous proximal tubule pressure monitoring to demonstrate distal nephron obstruction was confirmed initially by obstructing flow through the nephron by injecting a bone wax cast into a surface distal convolution after initiating perfusion. Proximal tubule pressure rose immediately toward stop-flow pressure, which was artificially varied between 30 and $50 \mathrm{~mm} \mathrm{Hg}$ by adjusting pressure in the perfusion apparatus. In every instance, proximal tubule pressures increased but, because of compliance of the perfused nephron, did not usually reach perfusion pressure.

During the microperfusion period, a 30-min inulin clearance was determined and, at the completion of the protocol, arterial blood was sampled for determination of hematocrit, plasma osmolality, and plasma concentrations of sodium, potassium, chloride, and protein. Rats were considered unsuitable for study if the arterial pressure fell below $100 \mathrm{~mm} \mathrm{Hg}$, the inulin clearance was $<400 \mu \mathrm{l} / \mathrm{min}$ per $100 \mathrm{~g}$ of BW, or proximal tubule pressure was $<10$ or $>17 \mathrm{~mm} \mathrm{Hg}$.
Dose-response study (series 1). In this group of experiments, rats were infused intravenously with Ringer-bicarbonate at $1.2 \mathrm{ml} / 100 \mathrm{~g}$ BW per hour after a $1-\mathrm{ml}$ bolus. To establish the dependence of intraluminal obstruction on the concentration of light chain in the perfusate, BJP3 was added to artificial tubular fluid in concentrations that ranged between 0.0001 and $1.0 \mathrm{mg} / \mathrm{ml}$ and single nephrons were perfused as described above. In addition, nephrons were perfused with BJP2 and ALB, both in a concentration of $1.0 \mathrm{mg} / \mathrm{ml}$.

Effect of extracellular fluid volume (series 2). During surgical preparation, rats were infused intravenously with Ringer-bicarbonate at 1.2 or $2.0 \mathrm{ml} / 100 \mathrm{~g}$ of BW per hour after a $1-\mathrm{ml}$ bolus. After a 1 -h equilibration period, isolated nephrons were perfused with artificial tubular fluid that contained BJP1, BJP2, or BJP3, $1 \mathrm{mg} / \mathrm{ml}$. Based upon these experiments, in subsequent studies described below all rats received intravenous fluids at $2.0 \mathrm{ml} / 100 \mathrm{~g}$ of BW per hour after a $1-\mathrm{ml}$ bolus.

Effect of loop diuretic (series 3). Isolated nephrons were perfused as described above with artificial tubular fluid that contained BJP3, 1 $\mathrm{mg} / \mathrm{ml}$, either alone or with furosemide (LymphoMed, Inc., Rosemont, IL), $10^{-5}$ or $10^{-4} \mathrm{M}$, added to the perfusate. These concentrations were chosen because of their use in literature demonstrating the pharmacologic activity of furosemide (19-21).

Effect of colchicine (series 4). Rats were anesthetized with ether, then a small incision was made in the skin over the upper thoracic vertebrae and a 2-ml pump (model 2ML1, Alza Corp., Palo Alto, CA) containing either colchicine or $\beta$-lumicolchicine (both from Sigma Chemical Co.), $1.9 \mathrm{mM}$, was inserted subcutaneously. The incision was then closed with 2-0 Polydek sutures. The animals were observed closely during recovery and then maintained on standard rat diet and tap water ad libitum in metabolic cages in order to collect their urine. Approximately $43 \mathrm{~h}$ after placement of the pumps, the rats were prepared for microperfusion as described above and isolated nephrons were perfused with $B J P 3,1 \mathrm{mg} / \mathrm{ml}$.

Turbidity measurements. The method to examine changes in turbidity of solutions has been detailed by us previously (15). TammHorsfall glycoprotein, purified from the urine of colchicine-pretreated, $\beta$-lumicolchicine-pretreated, and untreated rats, was used in these studies. The cast-forming Bence Jones protein, BJP3, in a final concentration of $0.03 \mathrm{mg} / \mathrm{ml}$, was added to solutions that contained each sample of the purified rat Tamm-Horsfall glycoprotein, $0.025 \mu \mathrm{g} / \mathrm{ml}$, in 125 $\mathrm{mM} \mathrm{NaCl}$. Changes in turbidity of these solutions was observed at a $90^{\circ}$ angle using a spectrofluorometer (Delta scan, Photon Technology International, Inc., South Brunswick, NJ) at an excitation and monitoring wavelength of $488 \mathrm{~nm}$. In separate experiments, while monitoring turbidity, furosemide, $10^{-4}$ to $10^{-6} \mathrm{M}$, was added to a solution containing Tamm-Horsfall glycoprotein, $0.025 \mu \mathrm{g} / \mathrm{ml}$, in $125 \mathrm{mM}$ $\mathrm{NaCl}$, then BJP3, in a final concentration of $0.03 \mathrm{mg} / \mathrm{ml}$, was added and changes in turbidity examined. This experiment was repeated with BJP3 added before furosemide.

Polyclonal rabbit antibody production/preparation. After collecting preimmune serum, a rabbit (Myrtle Rabbits, Thompson, TN) was injected intramuscularly with $800 \mu \mathrm{l}$ of purified rat Tamm-Horsfall glycoprotein, $0.5 \mathrm{mg}$, in complete Freund's adjuvant (Gibco, Grand Island, NY). 2 and 4 wk later, antibody production was boosted with intramuscular injections of protein in phosphate buffered saline. $6 \mathrm{wk}$ after the initial injection, dot blot of serum demonstrated sufficient titer $(1: 10,000)$ of antibody to rat Tamm-Horsfall glycoprotein to harvest the antiserum; dot blot of preimmune serum was negative. The antibody was purified with a protein A/G-agarose column (Affinica Protein A/G Agarose, Schleicher \& Schuell, Inc., Keene, NH) to harvest the immunoglobulin component of the antiserum. Subsequent purity was demonstrated with SDS-PAGE. Western blotting of rat urine and purified rat Tamm-Horsfall glycoprotein using this polyclonal antibody, 1:20 dilution, demonstrated specificity for rat Tamm-Horsfall glycoprotein. The antibody was stored at $-20^{\circ} \mathrm{C}$ until use.

Enzyme-linked immunosorbent assay (ELISA) of Tamm-Horsfall glycoprotein. Wells of a 96-well plate (Immuno Plate Maxisorp, Nunc, Kamstrup, Denmark) were coated using $100 \mu$ l of urine sample. In other wells, solutions containing known amounts of purified rat 
Tamm-Horsfall glycoprotein diluted in $0.1 \mathrm{M}$ borate-buffered saline (BBS), $\mathrm{pH} 8.2$, were determined simultaneously in order to generate a standard protein concentration curve. Wells were also incubated with $1 \%$ bovine serum albumin in BBS (BBS-BSA) alone to serve as controls. The plate was covered with plastic wrap and incubated overnight at $4^{\circ} \mathrm{C}$. All of the wells were then emptied, washed three times with BBS, then filled with BBS-BSA. The plate was incubated for $1 \mathrm{~h}$ at room temperature, then emptied and washed three times with the BBS. To each well, $100 \mu \mathrm{l}$ of the polyclonal rabbit anti-rat Tamm-Horsfall glycoprotein antibody, 1:500 dilution in BBS-BSA was added and the plate was incubated for $4 \mathrm{~h}$ at room temperature. The wells were emptied and washed four times with BBS. To each well was added $100 \mu \mathrm{l}$ of goat anti-rabbit IgG conjugated to horseradish peroxidase (Bio-Rad Laboratories, Richmond, CA) previously diluted 1:1000 in BBS-BSA. The plate was covered and incubated for $2 \mathrm{~h}$ at room temperature and then emptied and washed three times with BBS. $200 \mu \mathrm{l}$ of substrate buffer containing 3,3',5,5' tetramethylbenzidine in aqueous dimethylformamide (Bio-Rad Laboratories) was added to each well. The optical density of each of the samples was determined at $655 \mathrm{~nm}$ using a microplate reader (Thermo max $_{\max }$, Molecular Devices Corp., Menlo Park, CA). The amount of Tamm-Horsfall glycoprotein in each test sample was calculated from the optical densities of the standard protein concentration curve.

Carbohydrate analysis. Urine samples and Tamm-Horsfall glycoprotein purified from the urine of untreated rats and rats treated with colchicine and $\beta$-lumicolchicine underwent electrophoresis on $10 \%$ polyacrylamide gels containing $0.1 \%$ sodium dodecyl sulfate (SDSPAGE) followed by transfer onto nitrocellulose membranes (Bio-Rad Laboratories). Glycoconjugate analysis was then performed using a kit and the supplied protocol (Glycan Detection Kit, Boehringer-Mannheim Biochemicals, Indianapolis, IN). Briefly, hydroxyl groups of sugars were oxidized to aldehyde groups, which were then covalently linked to digoxigenin-labeled succinyl- $\epsilon$-amidocaproic acid hydrazide. These digoxigenin-labeled glycoconjugates were detected using an anti-digoxigenin antibody conjugated to alkaline phosphatase and substrate for alkaline phosphatase. In separate experiments, lectinbinding studies using a kit (Glycan Differentiation Kit, BoehringerMannheim Biochemicals) characterized further the carbohydrate moiety of purified rat Tamm-Horsfall glycoprotein, which had been electrophoresed using SDS-PAGE, and then transferred to nitrocellulose. Briefly, we used Sambucus nigra agglutinin (SNA), a lectin that binds specifically to $\mathrm{N}$-acetylneuraminic acid (sialic acid) terminally linked $\alpha(2-6)$ to galactose or $N$-acetylgalactosamine, and Maackia amurensis agglutinin (MAA), a lectin specific for sialic acid terminally linked $\alpha(2-3)$ to galactose. The nitrocellulose membrane was incubated for $1 \mathrm{~h}$ with each of these lectins, which had been conjugated to digoxigenin. After washing, the membrane was incubated for $1 \mathrm{~h}$ with an anti-digoxigenin antibody conjugated to alkaline phosphatase. The membrane was then washed and stained with substrate for alkaline phosphatase.

Analytical methods/statistical analysis. Detailed methodology for determination of inulin clearance, hematocrit, plasma osmolality, and plasma sodium, potassium, chloride, and protein concentrations has been reported (12). Values obtained at the start and completion of the microperfusion period were averaged for each rat. The Lowry method was used to quantitate urine protein excretion rate.

All values were represented as mean \pm SEM. Comparisons between experimental and corresponding control groups were analyzed for statistical significance by the unpaired $t$ test, or analysis of variance and the Scheffe $F$-test, where appropriate, using a statistical program (Statview 512+, Abacus Concepts, Inc., Berkeley, CA). Significance was set at the $5 \%$ level.

\section{Results}

In the following studies, mean perfusion pressure and proximal tubule pressure of all of the microperfusion experiments ( $n$ $=55$ rats) were $28 \pm 1$ and $13.8 \pm 0.2 \mathrm{~mm} \mathrm{Hg}$, respectively.

Obstruction occurred in the distal nephron in a concentration-dependence fashion (series 1). 27 animals were used in these studies (Table I). Perfusion of nephrons with BJP3 at all protein concentrations except those $\leq 0.001 \mathrm{mg} / \mathrm{ml}$ (Table II) consistently increased proximal tubule pressure from baseline to $\geq 20 \mathrm{~mm} \mathrm{Hg}$. In addition, perfusion took longer to raise proximal tubule pressure to $20 \mathrm{~mm} \mathrm{Hg}$ as the BJP3 concentration in the perfusate was decreased (Table II). BJP2, $1 \mathrm{mg} / \mathrm{ml}$, produced obstruction in five of six perfused nephrons within 60 min of perfusion. In contrast, proximal tubule pressure did not change during perfusion with ALB, $1 \mathrm{mg} / \mathrm{ml}$, for $60 \mathrm{~min}$.

Subsequent dissection of all of the nephrons that developed an increase in proximal tubule pressure when perfused with BJP2 and BJP3 showed casts in the distal nephron (Fig. 1), regardless of the protein concentration that was used. The site of obstruction varied from the thick ascending limb of the loop of Henle to the medullary collecting tubule. Dilatation of the nephron proximal to the site of obstruction was commonly observed. Casts were never identified in segments proximal to the ascending limb of the loop of Henle of these perfused nephrons. In those nephrons in which proximal tubule pressure did not increase, including the ALB-perfused nephrons, no casts were found.

Table I. Whole-Animal Data for the Four Series of Experiments

\begin{tabular}{|c|c|c|c|c|c|c|}
\hline Study & $\begin{array}{l}\text { Number of } \\
\text { animals }\end{array}$ & Body weight & Urine volume & $\begin{array}{l}\text { Inulin } \\
\text { clearance }\end{array}$ & $\begin{array}{l}\text { Plasma } \\
\text { protein }\end{array}$ & Hematocrit \\
\hline & & $g$ & \multicolumn{2}{|c|}{$\mu \mathrm{l} / \mathrm{min}$ per $100 \mathrm{~g} \mathrm{BW}$} & $g / d l$ & $\%$ \\
\hline Series 1 & 27 & $225 \pm 5$ & $6.7 \pm 1.1$ & $1142 \pm 101$ & $5.0 \pm 0.1$ & $48 \pm 0$ \\
\hline \multicolumn{7}{|l|}{ Series 2} \\
\hline Low infusion & 6 & $240 \pm 6$ & $6.8 \pm 2.4$ & $1,256 \pm 265$ & $5.2 \pm 0.1$ & $47 \pm 0$ \\
\hline High infusion & 16 & $236 \pm 3$ & $8.0 \pm 3.0$ & $1,026 \pm 95$ & $4.3 \pm 0.1$ & $44 \pm 0$ \\
\hline$P$ value & & & & & 0.0001 & 0.004 \\
\hline Series 3 & 6 & $238 \pm 8$ & $4.7 \pm 0.7$ & $1,304 \pm 154$ & $4.1 \pm 0.1$ & $44 \pm 1$ \\
\hline \multicolumn{7}{|l|}{ Series 4} \\
\hline Colchicine & 5 & $208 \pm 4$ & $10.0 \pm 1.4$ & $854 \pm 89$ & $5.2 \pm 0.2$ & $49 \pm 0$ \\
\hline$\beta$-Lumicolchicine & 4 & $236 \pm 9$ & $10.5 \pm 3.6$ & $854 \pm 207$ & $4.8 \pm 0.1$ & $44 \pm 1$ \\
\hline$P$ value & & 0.02 & & & & 0.0006 \\
\hline
\end{tabular}


Table II. Effect of Perfusate Protein Concentration on Intranephronal Obstruction

\begin{tabular}{llcccc}
\hline & $\begin{array}{c}\text { Protein } \\
\text { Protein }\end{array}$ & $\begin{array}{c}\text { Number of } \\
\text { concentration }\end{array}$ & $\begin{array}{c}\text { Baseline } \\
\text { proximal } \\
\text { perfusions }\end{array}$ & $\begin{array}{c}\text { Obstructed } \\
\text { tubule pressure }\end{array}$ & $\begin{array}{c}\text { Perfusion } \\
\text { duration }\end{array}$ \\
\hline & $m g / m l$ & & $m m ~ H g$ & & min \\
BJP3 & 0.0001 & 4 & $12.8 \pm 0.9$ & $3 / 4$ & $41.5 \pm 10.0$ \\
BJP3 & 0.001 & 5 & $14.3 \pm 0.6$ & $3 / 5$ & $33.7 \pm 11.7$ \\
BJP3 & 0.01 & 4 & $14.6 \pm 0.2$ & $4 / 4$ & $21.9 \pm 5.0$ \\
BJP3 & 0.1 & 4 & $13.7 \pm 1.0$ & $4 / 4$ & $33.3 \pm 1.4$ \\
BJP3 & 0.5 & 4 & $15.0 \pm 0.5$ & $4 / 4$ & $5.4 \pm 2.1^{*}$ \\
BJP3 & 1.0 & 6 & $13.6 \pm 0.4$ & $6 / 6$ & $6.0 \pm 1.3^{*}$ \\
BJP2 & 1.0 & 6 & $13.4 \pm 0.4$ & $5 / 6$ & $23.0 \pm 9.0$ \\
ALB & 1.0 & 4 & $14.9 \pm 0.8$ & $0 / 4$ & 60 \\
\hline
\end{tabular}

${ }^{*} P<0.003$, compared to BJP3 perfusions with concentrations $\leq 0.1$ $\mathrm{mg} / \mathrm{ml}$.

Extracellular fluid volume modulated intranephronal obstruction (series 2). To examine whether the state of hydration affected cast formation, nephrons of rats receiving intravenous fluids at either 1.2 or $2.0 \mathrm{ml} / 100 \mathrm{~g} \mathrm{BW}$ per hour were perfused with either BJP1 or BJP3, $1 \mathrm{mg} / \mathrm{ml}$. Mean plasma protein concentration and hematocrit were higher $(P<0.05)$ in the rats receiving fluids at the lower infusion rate (Table I). In those rats receiving fluids at the lower rate, obstruction, manifesting as an increase in proximal tubule pressure and the presence of cast material observed visually, occurred in all of the nephrons perfused with BJP1 and BJP3 (Table III). Casts were identified only in the distal nephron. In contrast, when BJP1 was perfused into nephrons of rats receiving fluids at the higher infusion rate, no evidence of obstruction was observed over $1 \mathrm{~h}$ of perfusion. Obstruction of the distal nephron occurred consistently during perfusion of BJP3 in these euvolemic rats, but took significantly longer to develop (Table III). The site of protein precipitation, the distal nephron, did not change with the state of hydration.

Furosemide aggravated obstruction (series 3). In this series of experiments ( $n=$ six rats; Table IV), nephrons were perfused with artificial tubular fluid that contained BJP3, $1 \mathrm{mg} / \mathrm{ml}$, alone or with furosemide, $10^{-5}$ or $10^{-4} \mathrm{M}$. Obstruction occurred in all of the perfused tubules regardless of the addition of furosemide in either concentration. However, obstruction developed more rapidly at the higher furosemide concentration. The site of cast formation in all of these tubules was the distal nephron and was not altered by furosemide.

In turbidity studies, addition of furosemide promoted, in a concentration-dependent fashion, aggregation of native rat Tamm-Horsfall glycoprotein in vitro (Fig. 2). Addition of furosemide after BJP3 to the solution containing Tamm-Horsfall glycoprotein did not affect the increase in turbidity. Furosemide also interacted in a concentration-dependent fashion with Tamm-Horsfall glycoprotein purified from rats treated
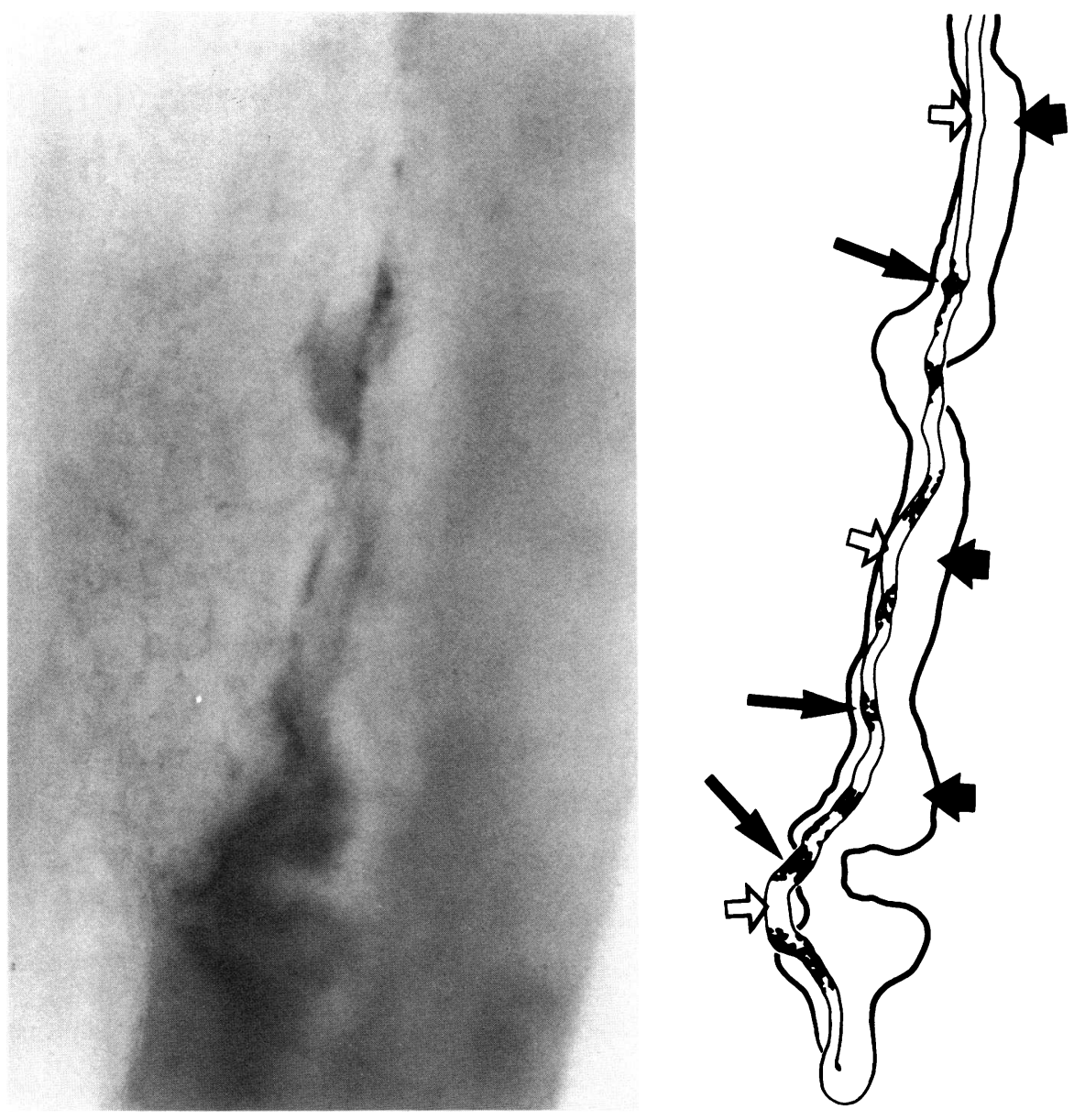

Figure 1. Photomicrograph of the loop segment of a nephron perfused with BJP3 (original magnification, $\times 40$ ). The cartoon at right represented the same perfused nephron. The ascending portion of the loop segment (white arrows) contained cast material (long black arrows) that occluded the lumen in several areas. The proximal portion of the loop segment (short black arrows) is dilated, demonstrating obstruction of the nephron by the cast material. 
Table III. Effect of Extracellular Fluid Volume on Intranephronal Obstruction by Bence Jones Proteins

\begin{tabular}{|c|c|c|c|c|c|}
\hline Group & $\begin{array}{l}\text { Infusion } \\
\text { rate }\end{array}$ & $\begin{array}{l}\text { Number of } \\
\text { perfusions }\end{array}$ & $\begin{array}{c}\text { Baseline } \\
\text { proximal } \\
\text { tubule pressure }\end{array}$ & $\begin{array}{c}\text { Obstructed } \\
\text { tubules }\end{array}$ & $\begin{array}{l}\text { Perfusion } \\
\text { duration }\end{array}$ \\
\hline & $\mathrm{ml} / 100 \mathrm{~g} B W$ per $h$ & & $\mathrm{~mm} \mathrm{Hg}$ & & $\min$ \\
\hline BJP1 & 1.2 & 4 & $12.0 \pm 0.4$ & $4 / 4$ & $20.7 \pm 6.2$ \\
\hline BJP1 & 2.0 & 5 & $13.6 \pm 0.4$ & $0 / 5$ & $60^{*}$ \\
\hline BJP3 & 1.2 & 6 & $13.6 \pm 0.4$ & $6 / 6$ & $6.0 \pm 1.3$ \\
\hline BJP3 & 2.0 & 14 & $13.6 \pm 0.3$ & $14 / 14$ & $15.0 \pm 2.1^{*}$ \\
\hline
\end{tabular}

Perfusate protein concentration was $1 \mathrm{mg} / \mathrm{ml}$.

${ }^{*} P<0.05$, compared to corresponding perfusions using the same protein in rats receiving fluids at the lower infusion rate.

with colchicine, but this interaction was less vigorous than that demonstrated with the native protein (Fig. 2).

Colchicine prevented obstruction by decreasing the tubular secretion and carbohydrate content of Tamm-Horsfall glycoprotein (series 4). Whereas rats receiving the colchicine infusion had lower body weights and higher hematocrits compared with rats that received $\beta$-lumicolchicine infusion, mean urine flow rates and inulin clearances did not differ (Table I). In rats pretreated with colchicine, proximal tubule pressure did not increase during perfusion for over $1 \mathrm{~h}$ with BJP3 (Fig. 3); subsequent dissection did not show casts in the lumens of these perfused nephrons (Table V). In contrast, $\beta$-lumicolchicine treatment did not prevent intraluminal obstruction and had no effect on the site or the time course of obstruction, compared with control perfusions using BJP3 in euvolemic rats (Table V).

Urine samples collected during the perfusion period demonstrated higher protein excretion rates in the colchicine-treated animals, compared with those rats treated with $\beta$-lumicolchicine $(0.43 \pm 0.06$ vs. $0.22 \pm 0.04 \mu \mathrm{g} / \mathrm{min} ; P=0.0257)$. SDSPAGE of these urine samples showed the increase in proteinuria related especially to an increase in excretion of low molecular weight proteins in these colchicine-treated rats (Fig. 4). In contrast to the increase in total protein excretion rate, colchicine treatment decreased the urinary excretion rate of TammHorsfall glycoprotein, compared with rats treated with $\beta$-lumicolchicine $(0.02 \pm 0.01$ vs. $0.08 \pm 0.02 \mu \mathrm{g} / \mathrm{min}, P=0.03)$.

Table IV. Effect of Furosemide on Intranephronal Obstruction by Bence Jones Proteins

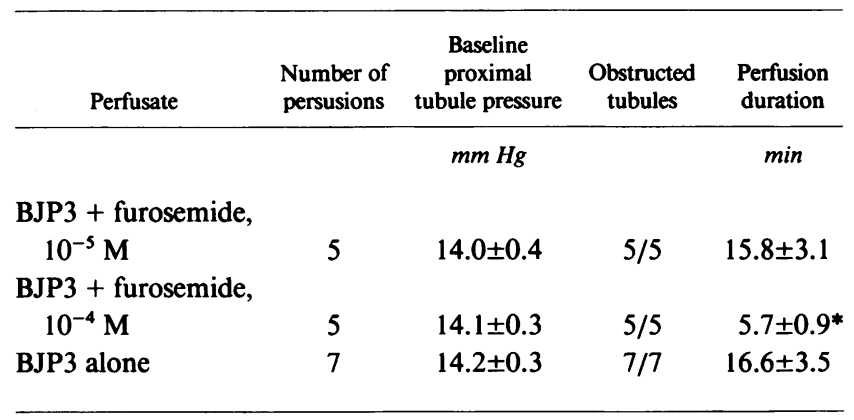

Perfusate protein concentration was $1 \mathrm{mg} / \mathrm{ml}$.

* $P<0.05$, compared to control and furosemide, $10^{-5} \mathrm{M}$, perfusions.
To examine whether the molecular form of Tamm-Horsfall glycoprotein was also modified with colchicine treatment, this protein was purified from the urine of untreated rats and rats treated with colchicine and $\beta$-lumicolchicine for two days. The interaction of these proteins with the cast-forming Bence Jones protein, BJP3, was observed in vitro (Fig. 5). This cast-forming Bence Jones protein, which has been shown to aggregate with human Tamm-Horsfall glycoprotein in vitro (15), readily aggregated with the native rat Tamm-Horsfall glycoprotein. In contrast, Tamm-Horsfall glycoprotein from animals that had received colchicine did not interact with BJP3 in vitro. Finally, Tamm-Horsfall glycoprotein from rats given $\beta$-lumicolchicine also aggregated with BJP3, although somewhat less avidly than did the native protein. Thus, in addition to preventing cast formation and decreasing excretion of Tamm-Horsfall glycoprotein by almost $80 \%$, colchicine treatment also altered the molecular form of secreted Tamm-Horsfall glycoprotein, preventing aggregation with Bence Jones protein in vitro.

Western blotting using polyclonal rabbit anti-rat TammHorsfall glycoprotein demonstrated the apparent molecular mass of Tamm-Horsfall glycoprotein purified from colchicinetreated rats was decreased to $\sim 60 \mathrm{kD}$, vs. $\sim 80 \mathrm{kD}$ for native Tamm-Horsfall glycoprotein and 60-80 kD for Tamm-Horsfall glycoprotein purified from the urine of rats treated with $\beta$-lumicolchicine. This reduction in apparent molecular mass was explained by lectin-binding analysis which showed a decrease in the carbohydrate content of Tamm-Horsfall glycoprotein with colchicine and to a lessor extent with $\beta$-lumicolchicine treatment. Terminal sialic acid residues on O-linked and $\mathrm{N}$-linked complex carbohydrates were not identified on Tamm-Horsfall glycoprotein from colchicine-treated rats (Fig. 6). Colchicine treatment also altered the carbohydrate content of other urinary proteins, compared with urine samples from rats that received $\beta$-lumicolchicine (Fig. 7).

\section{Discussion}

We have shown several new insights into the pathogenesis of cast nephropathy from Bence Jones proteins. Three human Bence Jones proteins (BJP2, BJP3, BJP4), but not ALB, consistently produced intranephronal obstruction by precipitating in the lumen of the distal nephron. Two of these proteins (BJP2 and BJP4) were from patients who had renal failure from cast nephropathy, or "myeloma kidney," documented with renal biopsy. The third protein (BJP3) was from a patient who had renal failure and multiple myeloma; this protein was demonstrated in other studies to precipitate in the distal nephron of rats in vivo and with human Tamm-Horsfall glycoprotein in vitro $(14,15)$. Obstruction from cast formation developed using protein concentrations within the reported range for serum concentrations of Bence Jones proteins in patients with multiple myeloma $(22,23)$, and was a concentration-dependent phenomenon (Table II). Thus, human Bence Jones proteins that produced renal failure and cast nephropathy reproduced distal nephron cast formation in our in vivo rat model that used single nephron perfusion. Because only cells of the thick ascending limb of the loop of Henle secrete Tamm-Horsfall glycoprotein $(16,17,24)$, normally this protein is present only in the lumen of the distal nephron. Together with other data showing the presence of this protein in casts $(16,17,25,26)$ and its ability to coaggregate with cast-forming Bence Jones proteins in vitro (15), the observation that casts were present only in the 

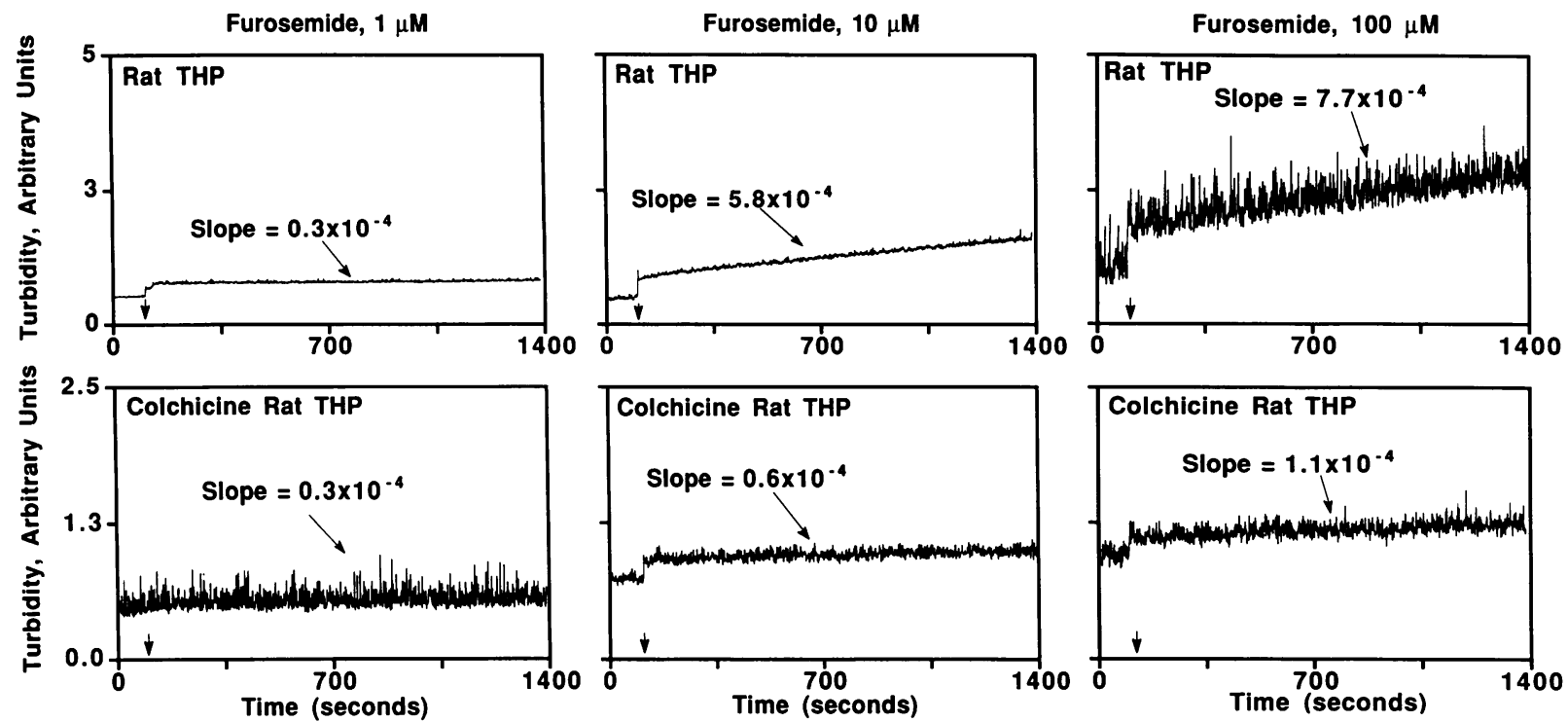

Figure 2. Effect of furosemide on change in turbidity of solutions that contained native rat Tamm-Horsfall glycoprotein (upper panels, labeled "rat THP") or Tamm-Horsfall glycoprotein obtained from rats pretreated with colchicine (lower panels, labeled "colchicine rat THP"). The concentration of furosemide added to the solution was shown above each column of figures. As the concentration of furosemide was increased from 1 to $100 \mu \mathrm{M}$, turbidity increased, as demonstrated by the increase in slope of the line representing the intensity of scattered light at $90^{\circ}$. Furosemide also increased turbidity in solutions containing colchicine rat THP, although the reaction was not as vigorous.

distal nephron was consistent with the integral role of TammHorsfall glycoprotein in cast nephropathy from Bence Jones proteins. In addition to the concentration of Bence Jones protein in the perfusate, extracellular fluid volume status of the animal, furosemide, and the amount and molecular form of Tamm-Horsfall glycoprotein affected distal nephron obstruction by these proteins.

Extracellular fluid volume was one important factor in the development of casts in our model. BJP1, obtained from a patient who had no clinically evident renal dysfunction, did not obstruct nephrons of euvolemic rats (Table III). In striking contrast, under conditions that produced mild extracellular fluid volume depletion, obstruction consistently occurred from

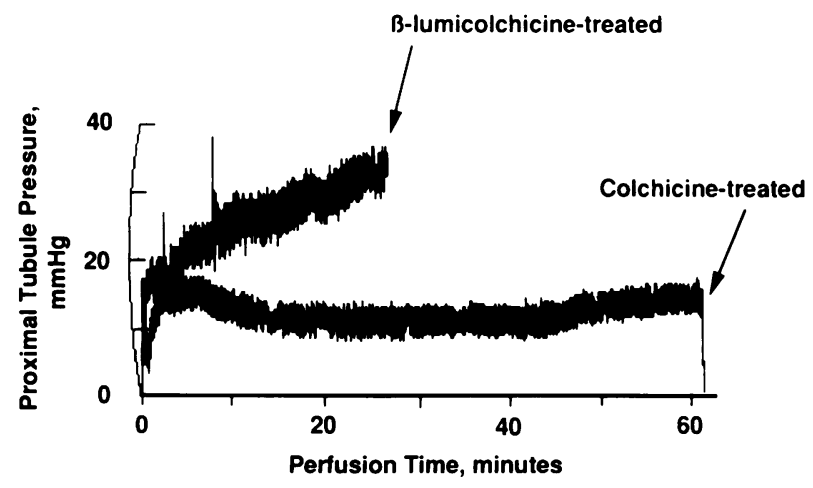

Figure 3. Two tracings of proximal tubule pressures observed during perfusion of BJP3, $1 \mathrm{mg} / \mathrm{ml}$, into nephrons of rats pretreated with either colchicine or $\beta$-lumicolchicine. Perfusion with BJP3 in the $\beta$ lumicolchicine-treated rat produced an acute increase in proximal tubule pressure; dissection subsequently demonstrated cast formation in the distal nephron. Proximal tubule pressure did not increase in the nephron of the colchicine-treated rat during perfusion with the same Bence Jones protein over $1 \mathrm{~h}$; cast material was not found in this perfused nephron. precipitation of this same protein in the distal nephron. Increasing the rate of intravenous fluid administration did not prevent obstruction from perfusion with BJP3, a cast-forming protein, but prolonged the time required for obstruction to develop.

Furosemide, a potent loop diuretic, has been used routinely to increase urinary flow rates in the setting of acute renal failure (27). The role of furosemide in the prevention and treatment of renal failure in multiple myeloma has not been tested. We have shown previously that increasing the concentration of sodium chloride facilitated coprecipitation of Bence Jones proteins with human Tamm-Horsfall glycoprotein in vitro (15). Thus, we postulated that furosemide promoted intranephronal obstruction by increasing sodium chloride concentration in the distal nephron, the site of cast formation. In our current studies, furosemide accelerated in a concentration-dependent manner cast formation and subsequent obstruction of nephrons perfused in vivo with cast-forming Bence Jones protein (Table

Table V. Effect of Microtubule Disruption on Intranephronal Obstruction by Bence Jones Proteins

\begin{tabular}{lcccc}
\hline \multicolumn{1}{c}{ Group } & $\begin{array}{c}\text { Number of } \\
\text { perfusions }\end{array}$ & $\begin{array}{c}\text { Baseline proximal } \\
\text { tubule pressure }\end{array}$ & $\begin{array}{c}\text { Obstructed } \\
\text { tubules }\end{array}$ & $\begin{array}{c}\text { Perfusion } \\
\text { duration }\end{array}$ \\
& & $m m ~$ & & $\min$ \\
Colchicine & 5 & $13.6 \pm 0.3$ & $0 / 5$ & $60^{*}$ \\
$\beta$-Lumicolchicine & 5 & $12.5 \pm 0.4$ & $5 / 5$ & $11.1 \pm 4.7$ \\
Untreated & 14 & $13.8 \pm 0.6$ & $14 / 14$ & $15.0 \pm 2.2$
\end{tabular}

Perfusions obtained in rats pretreated with colchicine were compared with perfusions from $\beta$-lumicolchicine-treated and untreated rats. Perfusate protein concentration was $1 \mathrm{mg} / \mathrm{ml}$.

${ }^{*} P<0.05$ vs. perfusions in $\beta$-lumicolchicine-treated and untreated rats. 


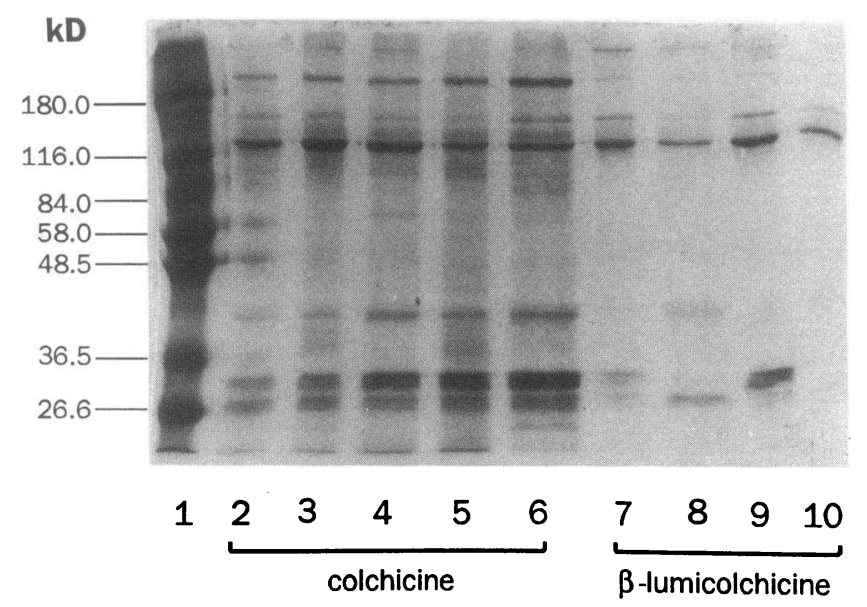

Figure 4. SDS-PAGE, using $10 \%$ polyacrylamide gels, of timed urine samples obtained from rats pretreated with colchicine (lanes 2-6) or $\beta$-lumicolchicine (lanes 7-10). Urine volumes were made equivalent before loading onto the gel. Urine of colchicine-treated rats contained greater amounts of proteins of all molecular weights, but especially proteins $<116 \mathrm{kD}$.

IV). In addition, however, when examined in vitro, furosemide catalyzed independently and in a dose-dependent fashion aggregation of rat Tamm-Horsfall glycoprotein in vitro by binding directly to the glycoprotein (Fig. 2). Other investigators have shown that furosemide binds to Tamm-Horsfall glycoprotein (28), although these results are controversial (29). Our studies suggested that furosemide enhanced cast formation by facilitating coprecipitation of these proteins indirectly by increasing distal nephron sodium chloride concentration and directly by binding to Tamm-Horsfall glycoprotein.

Colchicine prevented obstruction from cast formation during perfusion of the nephron with a cast-forming Bence Jones protein. $\beta$-Lumicolchicine, an isomer of colchicine, does not bind tubulin but does possess other properties of colchicine, including inhibition of protein synthesis. It has been routinely used as a control for colchicine $(30,31)$. In our study, treatment with $\beta$-lumicolchicine did not prevent obstruction of the perfused nephron. Although colchicine increased urinary total protein excretion rate, possibly by decreasing endocytosis of low molecular weight proteins by the proximal tubule $(32,33)$, urinary excretion rate of Tamm-Horsfall glycoprotein decreased. This latter finding was consistent with the observation that colchicine decreased apical secretion of an $80-\mathrm{kD}$ protein in MDCK cells (34). Decreased secretion of Tamm-Horsfall glycoprotein was probably one factor that contributed to the prevention of intraluminal obstruction by Bence Jones proteins.

Colchicine also decreased the carbohydrate content, particularly sialic acid, of rat Tamm-Horsfall glycoprotein (Fig. 6). By doing so, coaggregation with the cast-forming Bence Jones protein did not occur in vitro (Fig. 5). Presumably, this factor contributed significantly to the prevention of intranephronal obstruction from cast formation in vivo (Fig. 3). In contrast, Tamm-Horsfall glycoprotein from untreated rats and from those rats treated with $\beta$-lumicolchicine coaggregated with the same cast-forming Bence Jones protein in vitro. These data suggested that the binding site on this glycoprotein for castforming immunoglobulin light chains was the carbohydrate
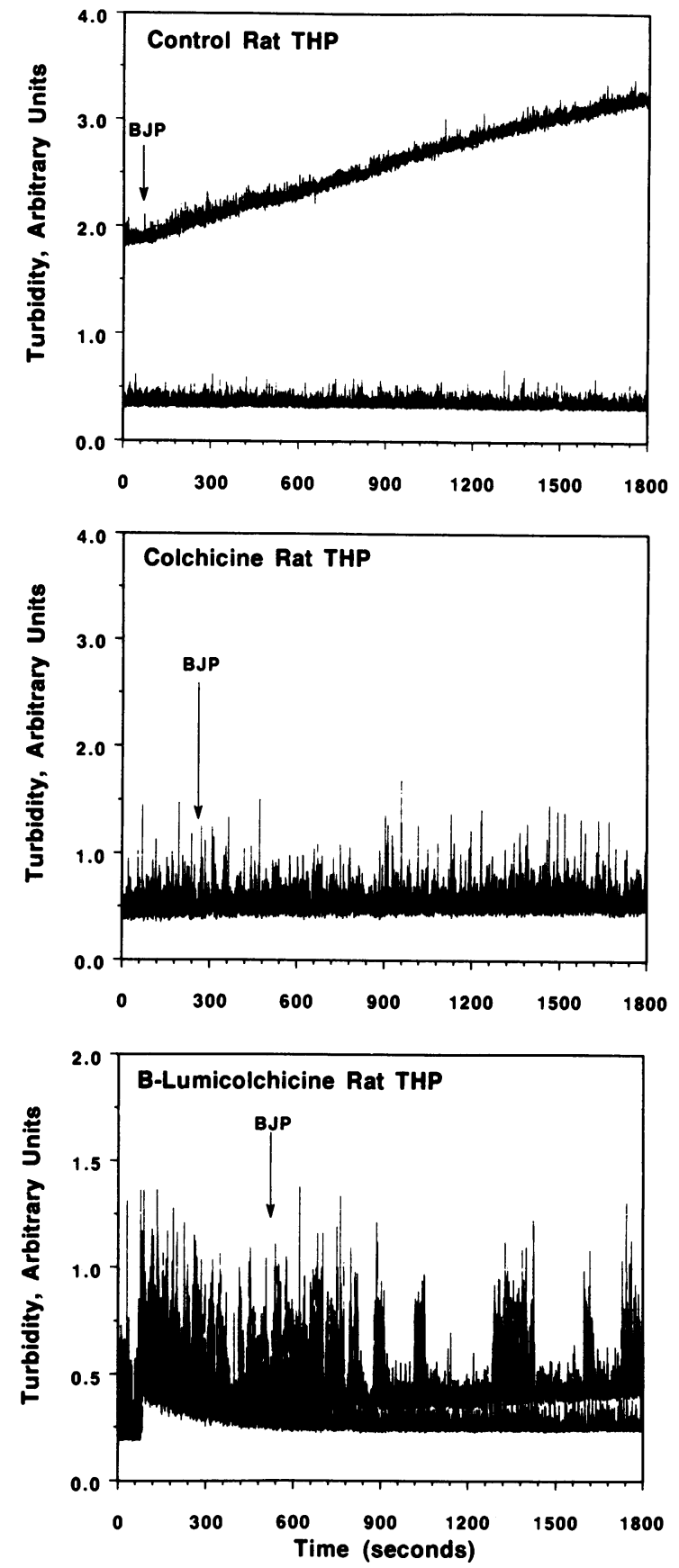

Figure 5. Light-scattering experiments using native Tamm-Horsfall glycoprotein (top panel, labeled "control rat THP"), Tamm-Horsfall glycoprotein from colchicine-treated rats (middle panel, labeled "colchicine rat THP"), and Tamm-Horsfall glycoprotein from $\beta$-lumicolchicine-treated rats (bottom panel, labeled "B-lumicolchicine rat THP"). In the top panel, addition of BJP3 rapidly increased turbidity of the solution, demonstrating coaggregation of this protein with the native Tamm-Horsfall glycoprotein. Addition of vehicle to the solution containing Tamm-Horsfall glycoprotein solution did not alter turbidity (lower tracing in the top panel). In the middle panel, addition of BJP3 to Tamm-Horsfall glycoprotein from colchicine-treated rats did not alter turbidity. In the bottom panel, addition of BJP3 to the solution containing Tamm-Horsfall glycoprotein from rats pretreated with $\beta$-lumicolchicine also increased turbidity. The increase in turbidity did not appear as significant as that observed when the native glycoprotein was used, but was greater than the change observed when vehicle alone was added (lower tracing in the bottom panel). 


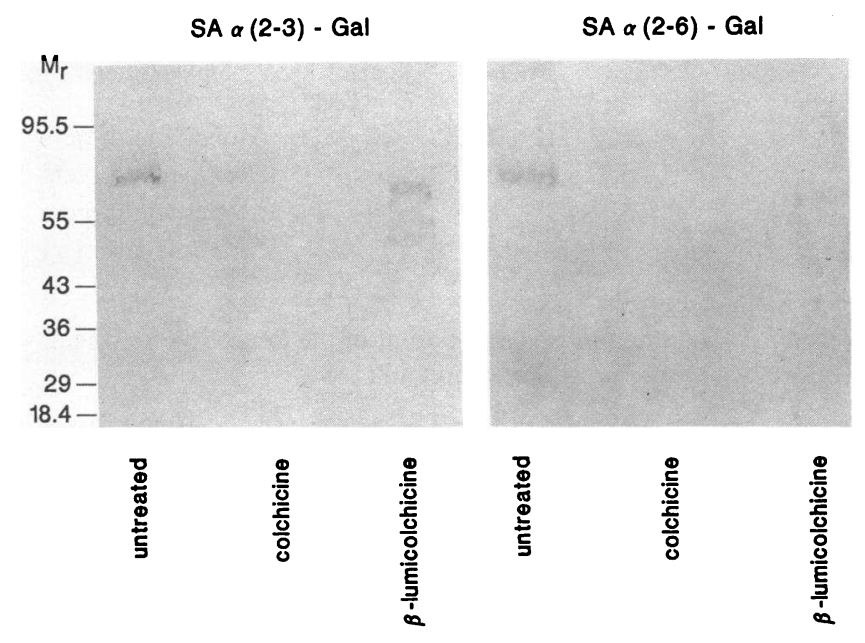

Figure 6. Lectin analysis of sialic acid content of Tamm-Horsfall glycoprotein obtained from untreated rats and rats pretreated with colchicine and $\beta$-lumicolchicine. These proteins had been electrophoresed using SDS-PAGE with $7 \%$ polyacrylamide gels, then transferred to a nitrocellulose membrane. By using a lectin that binds specifically sialic acid terminally linked $\alpha(2-6)$ to galactose or $N$-acetylgalactosamine (labeled "SA $\alpha(2-3)$ - Gal"), Tamm-Horsfall glycoprotein from untreated and $\beta$-lumicolchicine-treated rats was shown to possess sialic acid in this configuration, but was absent in Tamm-Horsfall glycoprotein from the colchicine-treated rats. Similarly, sialic acid terminally linked $\alpha(2-3)$ to galactose was present in Tamm-Horsfall glycoprotein from untreated rats and rats treated with $\beta$-lumicolchicine, but was absent in Tamm-Horsfall glycoprotein from colchicinetreated rats (labeled "SA $\alpha(2-3)-$ Gal"). Molecular mass markers at left are in kilodaltons.

moiety. Binding of other proteins, such as interleukin 1, interleukin 2 , and tumor necrosis factor, also depended upon the carbohydrate side chains of Tamm-Horsfall glycoprotein (17). Binding of furosemide to the glycoprotein appeared to be at a site different from the light chain binding site because furose- mide, but not BJP3, continued to interact with Tamm-Horsfall glycoprotein from colchicine-treated rats (Fig. 2).

Certain physicochemical properties of the immunoglobulin light chain are necessary but not sufficient factors provoking protein cast formation. Some Bence Jones proteins have been shown to be nontoxic despite excretion of gram amounts of these proteins in the urine $(7,35)$. It is known that Bence Jones proteins produce renal failure from different types of lesions. Some proteins show a propensity to precipitate in the tubule lumen, while others produce amyloid deposits (7). However, defining the particular property conferring nephrotoxicity has proved elusive. Cast formation is not related to a particular isotype or molecular form of the light chain $(5,7,8)$. The effect of the isoelectric point of the light chain on cast formation has been controversial $(5,7,10,15,36)$. We have shown previously that isoelectric point correlated with aggregation with human Tamm-Horsfall glycoprotein in vitro; those proteins possessing net negative charges (isoelectric point $<5.1$ ) showed no interaction with this glycoprotein (15). In vivo, however, not all cationic proteins produce cast formation, in part because of changes that can occur in the distal nephron concentration of sodium chloride, which modulates coaggregation of these proteins (15). Other factors affect obstruction from cast formation. In the present study, although isoelectric points of the Bence Jones proteins were similar (Table VI), BJP1 did not precipitate in vivo unless perfused into nephrons of rats that had mild extracellular fluid volume depletion, which promoted obstruction from cast formation. From the combined data, there appears to be an electrostatic interaction between cast-forming Bence Jones proteins and the carbohydrate side chains of Tamm-Horsfall glycoprotein; this interaction is a major determinant of aggregation in vitro and is therefore necessary for cast formation to occur. However, the binding interaction (and therefore the consequent physiologic manifestation of intranephronal obstruction) is modulated by the electrolyte composition of the distal nephron (15); the extracellular fluid volume status which alters distal nephron fluid absorption, electrolyte composition and flow rate; the presence of the loop diuretic
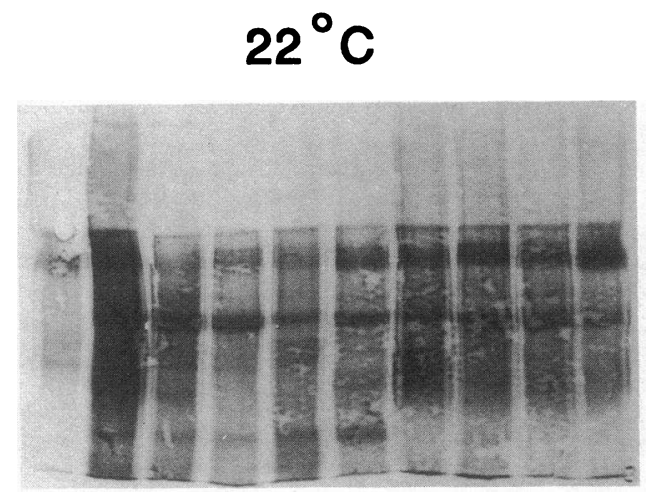

$\begin{array}{llllllllll}1 & 2 & 3 & 4 & 5 & 6 & 7 & 8 & 9 & 10\end{array}$

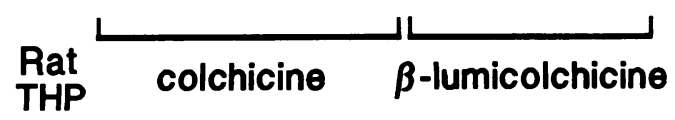

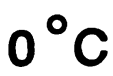
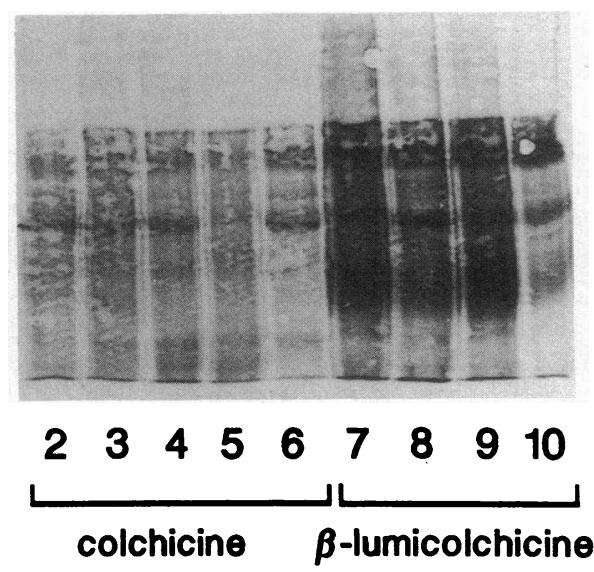

Figure 7. Glycoconjugate analysis of urinary proteins from rats pretreated with either colchicine or $\beta$-lumicolchicine. The urine samples and native rat TammHorsfall glycoprotein (THP) were electrophoresed using SDSPAGE with $10 \%$ polyacrylamide gels, then transferred to a nitrocellulose membrane. Glycoproteins were detected using digoxigenin-labeled hydrazide compound followed by anti-digoxigenin antibodies conjugated to alkaline phosphatase and substrate for alkaline phosphatase. When reacted at $22^{\circ} \mathrm{C}$, the reaction appeared qualitatively similar (first gel), although significantly more protein was

loaded into lanes 2-6, because colchicine increased urinary excretion of proteins (see also Fig. 4). However, when reacted at $0^{\circ} \mathrm{C}$ (second gel), the reaction was relatively specific for sialic acid (see reference 42), and demonstrated a definite decrease in sialic acid content in proteins from colchicine-treated rats. 
Table VI. Physicochemical Characteristics of the Four Bence Jones Proteins Used in These Studies

\begin{tabular}{lcccccc}
\hline Protein & $\begin{array}{c}\text { Clinical renal } \\
\text { failure }\end{array}$ & $\begin{array}{c}\text { Histology } \\
\text { (human) }\end{array}$ & $\begin{array}{c}\text { Distal nephron } \\
\text { cast formation }\end{array}$ & Isotype & \multicolumn{1}{c}{$\begin{array}{c}\text { Isoelectric point } \\
\text { (range) }\end{array}$} & Molecular form \\
\hline BJP1 & No & - & No* $^{*}$ & $\kappa$ & $5.4^{\ddagger}(5.2-6.5)$ & Monomers/dimers \\
BJP2 & Yes & Cast nephropathy & Yes & $\kappa$ & $5.2,5.3,5.4^{\ddagger}(5.2-6.6)$ & Monomers/dimers \\
BJP3 & Yes & Unknown & Yes & $\lambda$ & $5.6,5.7^{\ddagger}(5.6-6.3)$ & Monomers/dimers \\
BJP4 & Yes & Cast nephropathy & Yes & $\kappa$ & $5.9^{\ddagger}(5.4-8.5)$ & Monomers/dimers \\
\hline
\end{tabular}

* Cast formation occurred under conditions of extracellular fluid volume depletion. ${ }^{\ddagger}$ Predominant isoelectric point of the Bence Jones protein.

${ }^{8}$ Histology of rat nephrons perfused with BJP3 demonstrated intraluminal cast formation from precipitated protein (14).

furosemide; and the degree of glycosylation of Tamm-Horsfall glycoprotein.

In summary, immunoglobulin light chains obtained from humans who had renal failure from cast nephropathy obstructed perfused nephrons of rats by precipitating in the lumen of the distal nephron. Obstruction was related to the concentration of the protein, which coprecipitated with TammHorsfall glycoprotein after binding to the carbohydrate moiety of this glycoprotein. Furosemide, by binding to Tamm-Horsfall glycoprotein at a site probably different from the light chain binding site and by increasing sodium chloride concentration in distal tubule fluid, augmented obstruction by light chains in a dose-dependent fashion. To the extent that these results may be relevant to cast nephropathy in humans, our study suggested that distal nephron obstruction is the principal cause of renal failure in cast nephropathy occurring in the setting of multiple myeloma. Tanner and Evan (37) have shown that within 1 mo of placement of wax casts in the proximal portion of the nephron, atrophy of the more proximal segments, severe damage to the more distal segments, and adjacent interstitial fibrosis developed. Foreign body reaction would damage further the nephron $(4,6)$. Thus, in the management of cast nephropathy, chemotherapy and treatment of hypercalcemia $(38,39)$, maintenance of euvolemia and even creation of polyuria (40), alkalinization of the urine (41), and avoiding furosemide, especially in high doses, could serve to prevent further cast formation. Finally, our studies suggested a role for colchicine in the acute management of these patients by allowing sufficient time for chemotherapy to decrease urinary immunoglobulin light chain excretion. These observations await clinical confirmation, but potentially offer new treatment for renal failure, the second leading cause of death in patients with multiple myeloma (39).

\section{Acknowledgments}

The authors thank Dr. Alan Solomon at the University of Tennessee Medical Center at Knoxville, for donating two of the proteins used in these studies. We also thank the Media Service of the Veterans Administration for the illustrations and photography.

This work was supported by the Research Service of the Veterans Administration, a biomedical research support grant from the University of Alabama at Birmingham, a George M. O'Brien Kidney and Urological Research Centers Program (National Institutes of Health P50DK-39258), and a grant from the University of Alabama Hospital.

\section{References}

1. Jones, H. B. 1847. Papers on chemical pathology: prefaced by the Gulstonian lectures, read at the Royal College of Physicians, 1846. Lancet. 2:88-92.

2. Edelman, G. M., and J. A. Gally. 1962. The nature of Bence-Jones proteins: chemical similarities to polypeptide chains of myeloma globulins and normal $\gamma$ globulins. J. Exp. Med. 116:207-227.
3. Solomon, A. 1976. Bence-Jones proteins and light chains of immunoglobulins. N. Engl. J. Med. 294:17-23.

4. Pirani, C. L., F. G. Silva, and G. B. Appel. 1983. Tubulo-interstitial disease in multiple myeloma and other nonrenal neoplasias. In Tubulo-interstitial Nephropathies. R. S. Cotran, B. M. Brenner, and J. H. Stein, editors. Churchill Livingstone, New York. 287-334.

5. Smolens, P. 1987. The kidney in dysproteinemic states. AKF Nephrol. Lett. 4:27-42.

6. Silva, F. G., C. L. Pirani, R. Mesa-Tejada, and G. S. Williams. 1982. The kidney in plasma cell dyscrasias: a review and a clinicopathologic study of 50 patients. In Progress in Surgical Pathology. C. E. Fenoglio and M. Wolff, editors. Masson, New York. 131-176.

7. Solomon, A., D. T. Weiss, and A. A. Kattine. 1991. Nephrotoxic potential of Bence Jones proteins. N. Engl. J. Med. 324:1845-1851.

8. Sanders, P. W., G. A. Herrera, K. A. Kirk, C. W. Old, and J. H. Galla. 1991. The spectrum of glomerular and tubulointerstitial renal lesions associated with monotypical immunoglobulin light chain deposition. Lab. Invest. 64:527-537.

9. McIntire, K. R., and M. Potter. 1964. Studies of thirty different Bence Jones protein-producing plasma cell neoplasms in an inbred strain of mouse. $J$. Natl. Cancer Inst. 33:631-648.

10. Weiss, J. H., R. H. Williams, J. H. Galla, J. L. Gottschall, E. D. Rees, D. Bhathena, and R. G. Luke. 1981. Pathophysiology of acute Bence-Jones protein nephrotoxicity in the rat. Kidney Int. 20:198-210.

11. Smolens, P., M. Venkatachalam, and J. H. Stein. 1983. Myeloma kidney cast nephropathy in a rat model of multiple myeloma. Kidney Int. 24:192-204.

12. Sanders, P. W., G. A. Herrera, and J. H. Galla. 1987. Human Bence Jones protein toxicity in rat proximal tubule epithelium in vivo. Kidney Int. 32:851861.

13. Sanders, P. W., G. A. Herrera, R. L. Lott, and J. H. Galla. 1988. Morphologic alterations of the proximal tubules of patients with light chain-related renal disease. Kidney Int. 33:881-889.

14. Sanders, P. W., G. A. Herrera, A. Chen, B. B. Booker, and J. H. Galla. 1988. Differential nephrotoxicity of low molecular weight proteins including Bence Jones proteins in the perfused rat nephron in vivo. J. Clin. Invest. 82:20862096.

15. Sanders, P. W., B. B. Booker, J. B. Bishop, and H. C. Cheung. 1990. Mechanisms of intranephronal proteinaceous cast formation by low molecular weight proteins. J. Clin. Invest. 85:570-576.

16. Hoyer, J. R., and M. W. Seiler. 1979. Pathophysiology of Tamm-Horsfall protein. Kidney Int. 16:279-289.

17. Kumar, S., and A. Muchmore. 1990. Tamm-Horsfall protein-uromodulin (1950-1990). Kidney Int. 37:1395-1401.

18. Tamm, I., and F. L. Horsfall, Jr. 1950. Characterization and separation of an inhibitor of viral hemagglutination present in urine. Proc. Soc. Exp. Biol. Med. 74:108-114.

19. Burg, M., L. Stoner, J. Cardinal, and N. Green. 1973. Furosemide effect on isolated perfused tubules. Am. J. Physiol. 225:119-124.

20. Kirchner, K. A. 1991. Indomethacin antagonizes furosemide's intratubular effects during loop segment microperfusion. J. Pharmacol. Exp. Ther. 243:881-886.

21. Kirchner, K. A., J. R. Voelker, and D. C. Brater. 1990. Intratubular albumin blunts the response to furosemide-a mechanism for diuretic resistance in the nephrotic syndrome. J. Pharmacol. Exp. Ther. 252:1097-1101.

22. Epstein, W. V., P. F. Gulyassy, M. Tan, and A. I. Rae. 1968. Effect of renal homotransplantation on the metabolism of the light chains of immunoglobulins. Ann. Intern. Med. 68:48-62.

23. Solomon, A., and J. L. Fahey. 1964. Bence Jones proteinuria. Am. J. Med. 37:206-222.

24. Bachmann, S., R. Metzger, and B. Bunnemann. 1990. Tamm-Horsfall protein-mRNA synthesis is localized to the thick ascending limb of Henle's loop in rat kidney. Histochemistry. 94:517-523.

25. McQueen, E. G. 1962. The nature of urinary casts. J. Clin. Pathol. 15:367-373. 
26. Cohen, A. H., and W. A. Border. 1980. Myeloma kidney: an immunomorphologic study of renal biopsies. Lab. Invest. 42:248-256.

27. Brezis, M., S. Rosen, and F. H. Epstein. 1991. Acute renal failure. In The Kidney. B. M. Brenner and F. C. Rector, editors. W. B. Saunders Co., Philadelphia. 993-1061.

28. Dulawa, J., M. Rambausek, K. Jann, M. Notohamiprodjo, and E. Ritz. 1985. Abnormal radiofurosemide binding by Tamm Horsfall glycoprotein of diabetic patients. Diabetologia. 28:827-830.

29. Brunisholz, M. C., K. L. Lynn, and J. S. Hunt. 1987. Loop-acting diuretics do not bind to Tamm-Horsfall urinary glycoprotein. Clin. Sci. (Lond.). 73:305310.

30. Stetson, D. L., and P. R. Steinmetz. 1983. Role of membrane fusion in $\mathrm{CO}_{2}$ stimulation of proton secretion by turtle bladder. Am. J. Physiol. 245 (Cell Physiol. 14):C113-120.

31. Gutmann, E. J., J. L. Niles, R. T. McCluskey, and D. Brown. 1989. Colchicine-induced redistribution of an apical membrane glycoprotein (gp330) in proximal tubules. Am. J. Physiol. 257 (Cell Physiol. 26):C397-C407.

32. Valberg, P. A., J. D. Brain, and D. Kane. 1981. Effects of colchicine or cytochalasin B on pulmonary macrophage endocytosis in vivo. J. Appl. Physiol. 50(3):621-629.

33. Piasek, A., and J. Thyberg. 1980. Effects of colchicine on endocytosis of horseradish peroxidase by rat peritoneal macrophages. J. Cell Sci. 45:59-71.

34. Parczyk, K., W. Haase, and C. Kondor-Koch. 1989. Microtubules are involved in the secretion of proteins at the apical cell surface of the polarized epithelial cell, Madin-Darby canine kidney. J. Biol. Chem. 264:16837-16846.

35. Woodruff, R., and B. Sweet. 1977. Multiple myeloma with massive Bence Jones proteinuria and preservation of renal function. Aust. N. Z. J. Med. 7:60-62.

36. Clyne, D. H., A. J. Pesce, and R. E. Thompson. 1979. Nephrotoxicity of Bence Jones proteins in the rat: importance of protein isoelectric point. Kidney Int. 16:345-352.

37. Tanner, G. A., and A. P. Evan. 1989. Glomerular and proximal tubular morphology after single nephron obstruction. Kidney Int. 36:1050-1060.

38. Bernstein, S. P., and H. D. Humes. 1982. Reversible renal insufficiency in multiple myeloma. Arch. Intern. Med. 142:2083-2086.

39. Kyle, R. A. 1975. Multiple myeloma: review of 869 cases. Mayo Clin. Proc. 50:29-40.

40. Bryan, C. W., and K. R. McIntire. 1974. Effect of sustained diuresis on the renal lesions of mice with Bence Jones protein-producing tumors. J. Lab. Clin. Med. 83:409-416.

41. Holland, M. D., J. H. Galla, P. W. Sanders, and R. G. Luke. 1985. Effect of urinary $\mathrm{pH}$ and diatrizoate on Bence Jones protein nephrotoxicity in the rat. Kidney Int. 27:46-50.

42. Haselbeck, A., and W. Hosel. 1990. Description and application of an immunological detection system for analyzing glycoproteins on blots. Glycoconjugate J. 7:63-74. 